\title{
Kritik af evidensbevægelsen
}

\author{
Af Carl Gustav Johannsen
}

\begin{abstract}
Denne artikel har som formål at prcesentere en rakke af de kritikpunkter, der fra forskellig side herhjemme har varet rettet mod evidensprincipperne og evidensbevagelsen i perioden fra midten af '90erne til $i$ dag. Herudover vil evidensteoriens relationer og berøringsflader til en rakke udvalgte samfundsvidenskabelige teorier blive behandlet. Artiklen vil lagge hovedvagten på den kritik mod og den debat, der har varet om evidensbevagelsen inden for uddannelsessektoren. Udover at systematisere i forhold til og referere til en rakke forskellige kritikpunkter vil argumenter og svar fra evidensbevagelsen også blive inddraget med henblik på at rette fejl og opklare eventuelle misforståelser. Det er en grundloeggende antagelse hos forfatteren af artiklen, at kritikken af evidensbaseret praksis i flere tilfoelde bygger pa misforståelser bl.a. i forhold til formålet med evidensbasering.
\end{abstract}

Carl Gustav Johannsen er cand.mag., ph.d. og lektor ved Det Informationsvidenskabelige Akademi. cgj@iva.dk

\section{Indledning}

Dette kapitel fokuserer på en række af de mere principielle kritikpunkter, der i Danmark har været rettet mod anvendelse af evidens baseret praksis (EBP) i den offentlige sektor. Kritikpunkterne stammer dels direkte fra de berørte sektorers - sundhed, social og uddannelse - praktikere og dels fra forskning. Især inden for uddannelsessektoren blev der - navnlig før Dansk Clearinghouse for Uddannelsesforskning ved DPU i 2006 påbegyndte sin virksomhed - formuleret ganske omfattende og skarpe kritikker af evidensprincipperne. Senere fra 2008 fandt også en egentlig debat sted i sektoren, idet de hidtil enerådende kritiske positioner nu blev imødegået af markante modindlæg fra centrale aktører i sektoren. Debatten i uddannelsessektoren er særlig interessant, fordi dele af den på mange måder ligner folkebibliotekerne.

Derimod vil jeg ikke gå nærmere ind på de kritikker, der i sundhedssektoren har været rettet mod evidens, da konteksten her er væsentlig forskellig for folkebibliotekernes. Endelig vil den kvantitativt langt mindre omfattende kritik stammende fra den sociale sektor også blive inddraget. Udover at redegøre for de forskellige kritiske positioner vil artiklen også omtale nogle af de konkrete anledninger, hvor kritikken er fremkommet og de aktører, der har ytret sig med henblik på at undersøge, hvilke interesser og professionsinteresser, der har været i spil. Jeg vil dog ikke nøjes med at redegøre for kritikken og kritikerne, men også prøve at belyse kritikkens holdbarhed ved at inddrage evidensbevægelsens svar og modar- 
gumenter. Yderligere vil jeg - som en supplerende tilgang - tillige forsøge at belyse positioner begrebet EBP i forhold til fem udvalgte samfundsvidenskabelige forskningsfelter (effektmåling, evalueringsteori, institutionel teori, organisationskultur og social kapital) med henblik på at vurdere graden af overlap og deres ofte komplekse indbyrdes relationer. Endelig vil afsnittet forsøge at vurdere, hvilken effekt kritikken har haft i forhold til evidensbevægelsen.

Empirisk bygger artiklen dels på to centrale debatindlæg og dels på en gennemgang af debatten i danske dagblade og fagtidsskrifter i ti-året 20002010 baseret på artikeldatabasen, Infomedia. Det ene centrale indlæg er Evidens i uddannelse? fra 2004, der er forfattet af en gruppe forskere fra Danmarks Pædagogiske Universitetsskole. Bogen omtales i "Social Kritik - Tidsskrift for social analyse \& debat" fra 2005 som et "kampskrift" og som et indlæg i en "kulturkamp" om retten til at definere de begreber, der skal bruges om pædagogik, opdragelse og undervisning (Social Kritik, 2005, nr. 102, s. 52): Det andet er Virker velfcerden - et debat oplceg om evidens og velfcerd udgivet af forlaget Mandag Morgen i 2004, og repræsenterer et nuanceret forsvar for evidenstankegangen. Publikationen er især vigtig som et korrektiv, idet EBP gang på gang af kritikerne blev - og måske stadig bliver - tillagt motiver og konsekvenser, som der slet ikke er belæg for. Begreber som EBP og evidensbevægelsen vil måske kunne opfattes som diffuse. Derfor skal jeg her præcisere, at min gengivelse af EBP primært stammer fra kilder som MandagMorgen (2004), Booth (2004) og Petticrew og Roberts (2006).

I artiklen vil jeg forsøge at besvare nedenstående seks forskningsspørgsmål:

1. I forbindelse med hvilke anledninger og kontekster er kritikken blevet fremsat?

2. Hvem og hvilke aktører står bag kritikken, og hvilke interesser har gjort sig gældende?

3. Hvilke kritikpunkter har der generelt og inden for de forskellige sektorer været rettet mod evidensbaseret praksis?

4. I hvilken udstrækning har kritikken hentet inspiration og legitimitet i udbredte samfundsvidenskabelige positioner?

5. Hvilken styrke har kritikken haft og i hvilken udstrækning har den rod i forskning og empiri?

6. Hvilken effekt har kritikken haft?
I artiklen vil det følgende afsnit "Kritikkens omfang og kronologi" beskæftige sig med forskningsspørgsmål nummer et. Afsnittet "Evidenskritiske argumenter og positioner" retter sig mod spørgsmål nummer to, mens spørgsmål tre behandles i de fem underafsnit: "Videnskabsteoretisk begrundet kritik", "Kritik med udgangspunkt i ønsket om professionelt råderum", "Evidens som udtryk for managementtænkning", "Evidens passer ikke til kulturen i dele af den offentlige sektor" og "Evidensbasering er skadelig for innovation og kreativitet”. Spørgsmål fire behandles i afsnittet "Evidens i samfundsvidenskabelige retninger" med underafsnittene: Effektmåling, evalueringsteori, institutionel teori, organisationskultur og social kapital. Spørgsmål seks bliver behandlet i afsnittet "Evidenskritikkens effekter." Endelig er der spørgsmål fem vedrørende kritikkens berettigelse og validitet. Dette spørgsmål vil indgå som en integreret del af alle afsnittene dog i særdeleshed i afsnit nummer tre.

\section{Kritikkens omfang og kronologi}

En søgning i Infomedia på artikler fra de sidste ti år (2000-2010), hvor ordet evidens forekommer, giver et resultat på lidt over 3.000 artikler. Bemærkelsesværdigt er det her, at halvdelen af artiklerne er publiceret inden for de seneste to år: 2009 og 2010. Tallet indicerer en markant stigende interesse for emnet $i$ offentligheden og blandt professionerne. Ser vi på, hvilke sektorer i samfundet, som artiklerne vedrører, ligger sundhedssektoren klart nummer et med anslået $75-80 \%$ af artiklerne. Ud fra titlerne at dømme rummer artiklerne en lang række eksempler på evidens eller mangel på evidens i sundhedssektoren inden for et meget bredt spektrum af emner fra effekter af unges solariebrug, af sygemelding og rekonvalescens efter hjertekirurgi til spørgsmålet om, hvorvidt private hospitaler er billigere og mere effektive end offentlige og effekter af "cyberkondri"( fejldiagnosticering via Nettet). Lidt principiel debat kan vi dog også finde inden for sundhedssektoren fx hos sygeplejersker (Smith, 2010), hvor der argumenteres imod evidensbaseret sygepleje med den begrundelse, at man dermed underkaster sig en tænkning, der placerer det meste af den sygeplejefaglige forskning på et lavt trin i hierarkiet. På andenpladsen kommer uddannelsessektoren, hvor debatten er markant mere principiel med argumenter for og imod EBP. Heri indgår også fra medio 2007 dokumenterede undersøgelsesresultater fx omkring evidens for effekten af 
nationale tests gennemført af Dansk Clearinghouse for Uddannelsesforskning på basis af de sidste 30 års internationale forskning om pædagogisk brug af tests (Nordenbo, 2010). Inden for den sociale sektor synes antallet af indlæg om evidens færre. Af principielle indlæg kan dog nævnes kronikken "Vi famler i blinde i socialpolitikken" (Søndergaard, 2010), der pointerer, at vejen til en mere professionel hjælp går over langt større fokus på, hvad der reelt virker. Den Infomedia baserede analyse viser yderligere, at evidensdebatten inden for bibliotekssektoren har været relativt sparsom, idet ordet evidens tilsyneladende kun er brugt ved en enkelt lejlighed i Bibliotekspressen inden for de seneste 10 år (frem til den 30.9.2010).

\section{Evidenskritiske argumenter og positioner}

Der har siden EBP vandt fodfæste herhjemme været rettet kritik mod den og specielt dens konsekvenser. Kritikken har været forskellig fra den ene sektor til den anden. Specielt inden for uddannelsessektoren har kritikken - især i en startfase - været kendetegnet ved en voldsom kritik. Afsenderne har tilsvarende varieret. Dels har praktikere repræsenterende de involverede professioner (læger, lærere, sygeplejersker, socialrådgivere, pædagoger, m.fl.) ytret sig kritisk og dels har forskere indenfor medicin, pædagogik, sociologi, antropologi, videnskabsfilosofi m.fl. markeret sig med kritiske bemærkninger og analyser. Der er i udlandet forekommet forskellige forsøg på at systematisere kritikpunkterne (fx Booth og Brice,2004a). Da disse er relativt forenklede, har jeg her forsøgt at nuancere ved at samle kritikken under følgende fem overskrifter:

1. Positivisme: Videnskabsteoretisk begrundet kritik. Påstand: EBP bygger på positivisme (Juul Jensen, 2004, samt Hjørland i dette temanummer)

2. Professionelt råderum: Kritik med udgangspunkt i ønsket om professionel autonomi. Påstand: EBP overflødiggør den enkelte professionelles faglige skøn

3. New Public Management. Påstand: EBP er udtryk for management og markedsorienteret tænkning

4. Kulturmismatch. Påstand: Centrale begreber inden for EBP (evidenshierarkiet, lodtrækningsforsøg (RCT) o.l.) passer ikke til kulturen og konteksten i uddannelses- og social sektoren - kampen mod evidens er led i en kulturkamp (Social Kritik; Moos, 2005)
5. Kreativitet. Påstand: Krav til evidens hæmmer kreativitet og innovation

Selvom der i praksis er betydelige overlap mellem de fem kritikpunkter, vil jeg behandle dem hver for sig.

\section{Videnskabsteoretisk begrundet kritik}

Den videnskabsteoretisk begrundede kritik finder vi på flere planer og i forskellige afskygninger. Argumentationen bygger typisk på at påvise lighedspunkter mellem evidensbevægelsens videnskabsteoretiske fundament og positivismen. Nu er konsekvenserne for en forsker af at få prædikatet positivist hæftet på sig næppe helt de samme som i 1970erne. Qvortrup synes da også - i 2008 - at tage risikoen for at blive kaldt for en endda "indskrænket positivist" ved at gå ind for evidens - ganske afslappet (Qvortrup, 2008b). Et centralt element er her en henvisning til stærke naturvidenskabelige elementer, der stammer fra, at evidensprincipperne oprindeligt blev udviklet inden for medicin. Typisk vil kritikken også hæfte sig ved, at et af evidensbevægelsens nøglebegreber, evidenshierarkiet, så utvetydigt prioriterer bestemte positivistiske undersøgelsesdesign - fx lodtrækningsforsøg, $\mathrm{RCT}$, - frem for fx kvalitative studier. I sin reneste form går kritikken ud på, at det er problematisk at sætte lighedstegn mellem videnskab og "naturvidenskabeligt funderet positivistisk forskning".

Samme kritik anfægter og problematiserer endvidere herudover en række begreber, som kritikken hævder er centrale i evidensbaseret videnskabsfilosofi: "sandheder" (sættes tilmed typisk i kursiv), sikker viden, entydige årsags-virknings sammenhænge, et "tendentielt monopoliserende evidens vidensbegreb", enkle opskrifter på god undervisning, m.m. Rieper og Foss Hansen (2007, s. 86-88) taler her om, at feltet på nogle områder og i visse lande er præget af "videnskabsideologiske forskansninger" samtidig med, at de ser tegn på mere "nuancerede holdninger til RCT og andre design". Det er her interessant - ikke mindst i forhold til det næste kritikpunkt, truslen mod den faglige autonomi - at Rieper og Foss Hansen ikke mener, at årsagen til forskellige syn på evidenshierarkiet skal forklares ud fra indholdet i de pågældende sektorers ydelser og opgaver, men at de mere hænger sammen med forskellige "fagprofessionelle traditioner" og "videnskabsteoretiske paradigmer". 
Debatten er ofte ledsaget af en ikke ubetydelig uklarhed i den videnskabsteoretiske argumentation. Der er således en stor forskel på, hvilke aspekter modviljen mod RCT omfatter. Et aspekt er problemstillingens karakter. I forhold til helt specifikke og snævre effektivitetsproblemstillinger af typen "hvad-virker", kan det således næppe betvivles, at RCT hører til de stærkeste design i den forstand, at designet har den største udsagnskraft og dermed producerer den sikreste viden. På andre punkter fx i forhold til omkostninger er forsøg med kontrolgrupper og systematisk måling ofte dyrere end projekter, hvor man interviewer en række personer (MandagMorgen, 2004, s. 29-30). Anderledes ser det ud ved andre relevante forskningsspørgsmål af typen "hvorfor-virker" eller "hvorfor-virker-ikke" i forhold til en bestemt indsats. Her vil være andre designs fx case-studier og kvalitative undersøgelser vise sig at være de optimale. Det giver anledning til at overveje, om ikke dele af den videnskabsteoretisk begrundede kritik beror på misforståelser og kommunikationsbrist. I den sammenhæng synes begrebet evidenstypologi, som det er udviklet af Rieper og Foss Hansen (2007, fig.7.1, side 79) stærkt i forhold til at demonstrere, hvilke spørgsmål, der egner sig til kvalitative designs, og hvilke spørgsmål der bedst besvares ved hjælp af lodtrækningsforsøg. Det er vigtigt her at pointere, at Rieper og Foss Hansen (2007) ikke med deres anbefaling af evidenstypologien frem for evidenshierarkiet problematiserer, at RCT er det optimale design i forhold til deciderede "effectiveness" og hvad-virker? orienterede forskningsspørgsmål.

Uffe Juul Jensen (2004), professor ved Institut for Filosofi ved Aarhus Universitet, henviser i en artikel til "faren ved at være mere katolsk end paven". Paven er i artiklen ingen ringere end Archie Cochrane, der ifølge Jensen var et "meget kritisk gemyt", der ikke havde til hensigt at ophøje en bestemt undersøgelsesmetode eller bestemte krav til design af videnskabelige undersøgelser til indiskutable trossætninger for sundhedsprofessionelle. Juul Jensen understreger, at Cochrane havde en "åben eller flerdimensionel opfattelse af evidens". Cochrane tilskriver således ikke resultater opnået gennem kontrollerede undersøgelser nogen absolut erkendelsesmæssig forrang frem for andre former for erfaringer. Tværtimod anerkender han, at "hverdagslivets erfaringer" i bestemte kontekster tilbyder en omfattende viden om, hvad der fremmer menneskelig sundhed og velbefindende. De kontrollerede lodtrækningsforsøg har derfor alene værdi i forhold til ganske bestemte sammenhænge, nemlig generelle terapeutiske hypoteser. Juul Jensen konkluderer, at mange:

"filosofiske og videnskabelige forviklinger skyldes en manglende omhyggelighed i brugen af ord og begreber, som måske ikke er så enkle og ligetil, som vi umiddelbart forestiller os".

På baggrund af ovenstående er det derfor reelt tvivlsomt, hvorvidt en anbefaling af forskellige andre videnskabelige paradigmer end positivismen som fx hermeneutik og fænomenologi med henblik på at "fange de praktiske, etiske og æstetiske dimensioner" (Moos, 2008, s. 20) reelt er i strid med en forestilling om, at RCT er det optimale design ved whatworks-problemstillinger. At RCT udgør det ideelt set optimale design betyder heller ikke, at RCT lader sig fuldt ud anvende på alle slags interventioner fx inden for biblioteksverdenen. Tværtimod bør man være opmærksom på , at evidenstænkningen som udgangspunkt er forholdsvis "dyr, langsom og især snæver og skarp". Den forudsætter derfor, at de services, som man ønsker at undersøge, bør være baseret på beskrivelige, veletablerede og stabile metoder, at de bør have fælles og anerkendte målsætninger og at de bør omfatte områder, hvor fejltrin er særligt problematiske (Mandagmorgen, 2004, side 33).

Konsekvensen af kritikken varierer også. I en mere moderat udgave anbefales det således, at supplere EBP med andre fx narrativt orienterede tilgang - og altså ikke helt at afvise EBP (Brophy, 2009, side 116).

\section{Kritik med udgangspunkt i ønsket om professio- nelt råderum}

Et andet kritikpunkt, som bl.a. forekommer i Moos (2008, side 7-8) går ud på, at evidensprincipperne truer den enkelte professionelles - in casu lærers professionelle råderum. I argumentationen indføres en sondring mellem begreberne "lokal evidens", der er sensitiv over for konkrete og specifikke, situationelle og individuelle forhold og "global evidens", der repræsenterer en kontekstuafhængig viden om, hvad der virker.

Det betones, at evidensbasering i pædagogisk praksis ikke kan erstatte den konkrete vurdering i det individuelle tilfælde, og evidensbevægelsen kritiseres for 
angiveligt at ignorere betydningen af, at lærerne som professionelle har et "rum" til selv at træffe afgørelser baseret på "skøn". Kritikerne frygter her, at "kogebogsopskrifter" og "manualisering", vil undergrave den personlige faglighed helt ned i den mindste detalje (Schultz Jørgensen, 2010). I den forbindelse tales om, at evidens inden for relationsprofessionerne bør afgøres gennem "kommunikativ validering" med "omfattende hensyn til den konkrete kontekst" (Moos, 2008, s. 27-28). Selvom det langtfra er krystalklart, hvad der konkret menes med "kommunikativ validering" virker kritikken umiddelbart rimelig. Problemet er bare, at evidensbevægelsen faktisk heller ikke indtager det synspunkt, som den her tillægges. Således skriver Mandagmorgen (2004, side 33) herom:

\footnotetext{
"Meget af det, der foregår i det personlige møde mellem offentligt ansat og bruger, kan ikke beskrives særligt præcist. I mange tilfælde kan det heller ikke styres, fordi deltagerne i mødet har forskellige personligheder, erfaringer og strategier. Det er et eksempel på et område, som ikke kan undersøges direkte ved hjælp af evidens. Evidens handler om forhold man kan - og bør - få under kontrol.”
}

Argumentationen for professionelt råderum eller autonomi får imidlertid en yderligere dimension, idet det antydes, at der findes "masser af evidens for karakteristika ved god undervisning", og at denne forskning til "formodentlig irritation for de evidenstroende og scientistiske" sætter læreren i centrum. Et andet sted gøres der opmærksom på, at forskning har påvist, at metoder, teknikker og undervisningsformer ikke har synderlig betydning for indlæringen, idet det er den kompetente lærers "konkrete beslutninger", der er afgørende (Moos, 2008, hhv. s. 36 og 41). Dette udsagn må vel siges at være særdeles abstrakt og på et meget højt generaliseringsniveau.

På den ene side hævder denne argumentation, at der ifølge de fem forskere ikke findes "enkle opskrifter" på god undervisning; på den anden side hævdes samtidig, at der er masser af evidens for, at $\mathrm{fx}$ en "klar struktur", brug af flere undervisningsformer og et struktureret indhold giver kvalitet $i$ undervisningen (Lihme, 2005a, s. 52). Ovennævnte ikke helt $100 \%$ konsistente ræsonnement illustrerer en interessant dobbelthed ved evidenstænkningen set ud fra et professionelt autonomi synspunkt. På den ene side kan forskningsbaseret viden give styrke til en profes- sion i form af prestige og tillid, og på den anden side kan den forskningsbaserede evidens i hænderne på politikere og brugere svække en professions autoritet og autonomi. Tænk fx på den betydning internettets adgang til lægevidenskabelig viden har haft for mange lægers professionelle autoritet. Det er på den baggrund et åbent spørgsmål om henvisninger til lærerens eget personlige faglige skøn styrker eller svækker dennes autoritet i forhold til en udmelding, hvor det individuelle skøn er suppleret med henvisninger til aktuel, eksisterende evidens.

Denne dobbelt- og tvetydighed i tilgange til evidens finder vi et slående eksempel på i Benny Lihmes (2005) introduktion til Social Kritiks temanummer om måling og evidens, hvor tilhængere af evidens satirisk omtales som "evidens-troende" og som tilhængere af et begyndende "tal- og kontrolgruppetyranni”.

Herefter analyseres to cases. Ifølge den ene case har en psykiater og en Rambøll-rapport begge refereret til angiveligt evidensbaserede undersøgelser, der skulle dokumentere gavnlige effekter af anvendelse af psykiatrisk tvang i eget hjem. Og Lihme fortsætter: "Indtil der for nylig dukkede et såkaldt Cochrane-review op" som lugede ud i de undersøgelser, som psykiateren og Rambøll havde vildledt ministeriet med. Han konkluderer, at den internationalt anerkendte undersøgelse viste, at der "ikke er evidens for at hævde, at tvang i eget hjem virker".

Den anden case handlede om et påstået evidensbaseret familiebehandlingsprogram, MST. Her viste et Campbell-review, at det pågældende program var blevet "falsk markedsført og over-solgt" til danske politikere.

Det bemærkelsesværdige ved de to cases er, at de sådan set begge dokumenterer udpræget positive effekter af EBP i den forstand, at Cochrane- og Campbell- rapporter af Lihme og Social Kritik bruges til at afsløre pseudovidenskabelige resultater og opblæst markedsføring. At den overordnede kontekst i øvrigt er ensidigt kritisk og eksplicit er vendt mod evidensbevægelsen gør ikke de to eksempler mindre interessante. Ligesom i det ovenstående eksempel virker det nemlig ikke, som om evidenskritikken herhjemme er specielt fri for ambivalens. 
En yderligere stramning af den professionsorienterede kritik nærmer sig en decideret videnskabsfjendtlig position, når den "intuitive, erfaringsbaserede, pædagogiske indsigt" fremhæves "frem for den pædagogiske videnskab, der i dag som evidensbaseret er blevet nærmest supervidenskabelig" (Madsen, 2008).

Forsvarere af evidens i uddannelsessektoren som $\mathrm{fx}$ Lars Qvortrup, DPU, vender problemstillingen omkring de af evidensprincipperne truede professionsinteresser helt om med en argumentation gående ud på, at lærerne skal bruge forskningsresultater i kommunikationen med forældrene. I sin argumentation inddrager han den historiske udvikling:

"På forældremøder skal lærerne kunne argumentere ordentligt for deres valg af undervisningsmetoder. I dag duer det ikke at sige, at sådan plejer vi at gøre. Tidligere var læreren den bedst uddannede kulturbærer i lokalsamfundet. Men sådan er det ikke i dag. Vi vil gerne øge respekten for lærerfaget ved at sikre lærerne ny forskning og gøre opmærksom på, at en god lærer er ekspert i undervisning og i klasserumsledelse" (Qvortrup, 2008a).

Han gør også op med den udbredte forestilling om, at man ikke kan generalisere og udlede almene konsekvenser inden for pædagogikken og ironiserer over forestillingen om, at evidens kun hører til i naturvidenskaben, mens sociale og psykologiske forhold er så "sarte" områder, at man ikke kan tale om evidens her. Modvilje mod evidens vil - ifølge Qvortrup - let kunne føre til at modparten kommer til at sætte dagsordenen (Qvortrup, 2008c).

Qvortrup er også ophavsmand til en anden vigtig pointe i evidensdebatten. Han påpeger, at ordet evidens har to forskellige betydninger: som noget 1) hverdagsagtigt indlysende og 2) som noget videnskabeligt bevist (Qvortrup, 2008b). Samtidig understreger han nødvendigheden af en konstruktiv dialog mellem den forsknings- og den praksisbaserede viden.

Sammenfattende kan man sige, at en omfattende frygt i visse professioner for, at EBP vil undergrave det faglige skøn og professionens autonomi savner belæg. Heller ikke Cochranes skrifter tyder på modvilje mod lægens individuelle faglige vurdering. Ydermere fremgår det, at der inden for professionerne synes at være stærkt divergerende forventninger til evidens, hvoraf den optimistiske del ser evidens som et middel til at styrke en professions anerkendelse, mens pessimisterne frygter, at evidens vil overflødiggøre det faglige jugement.

\section{Evidens er udtryk for managementtænkning}

Mange kritikere af evidens i uddannelsessektoren er ikke i tvivl om, at der ligger klare politiske styringsinteresser bag evidensbevægelsen. Grundlæggende samfundsmæssige værdier og interesser er på spil, idet det drejer bl.a. drejer sig om, hvem der skal fastsætte målene. Evidens berører således forholdet mellem politisk styring, professionsstyring og brugerindflydelse. Også "vidensdemokratiet" er i fare, idet evidenskritikerne anser det for problematisk, at viden monopoliseres og produceres "via særlige videnscentre eller kommercielt baserede "clearing-houses"

(Moos, 2008, s. 16-17).

Denne kritik er imidlertid væsensforskellig fra den kritik, der typisk rettes mod New Public Management- (NPM) tendenser i den offentlige sektor, hvor det er træk som etablering af kontrakt- og markedslignende køber-sælgerrelationer, kontraktstyring, udlicitering, privatisering, konkurrence, frit forbrugsvalg, osv., der er i spil (Johannsen og Pors,2002, s. 11-13). Der er yderligere grunde til, at kritikken af NPM kun har haft sporadisk indflydelse (se fx Ghosh, 2009) på debatten om evidens. Den vigtigste er utvivlsomt, at inspirationen til evidens slet ikke stammer fra det private erhvervsliv, men snarere handler om at knytte praksis i offentlige institutioner sammen med forskning. Inden for den medicinske sektor opfattes evidensbevægelsen således som et kritisk korrektiv til meget af den forskning, der forestås af medicinalindustrien (interview med Asbjørn Hrobjartsson den 12.maj2010). En tilsvarende kritisk distance til NPM ses hos Booth og Brice (2004a), hvor det siges direkte:

"During the late 1980s the preoccupation of monetarist governments with 'value for money' had done much to alienate professionals such as teachers, doctors and nurses who prefer to focus on quality og service. Within the health service, for example, cost-cutting managers were ranged against clinical 'champions' for public standards. Shifting the emphasis from economy (i.e. cost-effectiveness) to effectiveness, while not completely circumventing the cost debate, served to unite ma- 
nagers and professionals in pursuit of a common goal" (Booth og Brice, 2004, s. 4).

Noget tilsvarende kan læses hos Rieper og Foss Hansen (2007, s. 72), der noterer, at fokus ved RCTdesigns "oftest alene (er) på effektivitet og ikke på omkostningseffektivitet". Et andet eksempel på, at evidens ikke nødvendigvis understøtter en NPM dagsorden kan hentes i uddannelsessektoren, hvor Dansk Clearinghouse for Uddannelsesforskning i 2009 gennemførte en undersøgelse af de sidste 30 års internationale forskning om pædagogisk brug af tests. Undersøgelsen konkluderede bl.a., at der ikke er "forskningsmæssigt belæg" for, at testdata har en nyttig pædagogisk brug (Nordenbo, 2010). Inden for medicinsk evidensproduktion er der eksempler på, at lægemiddelindustrien har anklaget Det Nordiske Cochrane Center for videnskabelig uredelighed (Gøtzsche, 2009), hvilket understreger centrets uafhængig af økonomiske interesser.

På den baggrund synes det godtgjort, at NPM-kritikken ikke er relevant i forhold til EBP.

\section{Evidens passer ikke til kulturen i dele af den of- fentlige sektor}

Argumentationen bag denne kritik minder i flere henseender om den kritik, der lægger vægt på, at evidens truer det professionelle skøn og den professionelle autonomi. I den udstrækning den professionelles autonomi udgør et centralt element i et biblioteks, en skoles eller et hospitals selvforståelse og kultur harmonerer de to kritikformer da også i vid udstrækning med hinanden. Der hvor de er forskellige drejer sig om organisationskulturens betydning for både intern effektivitet og ekstern konkurrenceevne. En af de mest kraftfulde mekanismer i forbindelse med skabelse og fastholdelse af en organisationskultur handler om, hvad ledelsen - og kolleger for den sags skyld - lægger mærke til, måler og kontrollerer, idet det sender tydelige signaler om prioriteringer, værdier og overbevisninger.

Et stærkt og konsekvent fokus på evidens fra en biblioteksledelses side vil derfor kunne mærkes på en måde, hvor det kolliderer med grundlæggende værdier og antagelser hos personalet. En af følgerne kunne være en modreaktion i form af udvikling af evidensskeptiske sub- og modkulturer i biblioteket. Pointen her er, at henvisninger til organisationskultu- ren både kan bruges til at forsvare EBP eller som et angreb herpå. I det første tilfælde kan man argumentere med, at institutionens kultur med en skeptisk eller afvisende holdning til EBP kan skade dens troværdighed og image og dens grundlæggende funktioner indadtil, mens man i det andet kan argumentere med, at indførelse af EBP i modstrid med medarbejdernes værdier vil skade fx sammenhængskraften eller skabe ufrugtbar splid. Inden for forskningsfeltet organisationskultur er der imidlertid også betydelige meningsforskelle fx om hvorvidt kultur er en manipulerbar størrelse og om hensigtsmæssigheden af det rationalistiske integrationsparadigme, der antager, at subkulturer er i modstrid med en effektiv målopfyldelse (Schultz, 1990, s. 11-25).

Specielt i vore nordiske nabolande, Norge og Sverige, spiller kulturfaktoren tilsyneladende en vigtig rolle i bibliotekssammenhænge. Interviews og litteratur peger på en vis modvilje mod EBP's tætte tilknytning til naturvidenskabelig-medicinsk traditioner, og en deraf afledt tendens til i det hele taget at undgå begrebet evidens og i stedet anvende alternative begreber såsom "kunnskapsbasert praksis" (Gjersdal, 2010; Audunson, 2009) eller "erfarenhets-baserat" praksis (Ögland, 2010).

\section{Evidensbasering er skadelig for innovation og kreativitet}

Evidensbaseret praksis er blevet fortolket som et normativt krav om, at al praksis principielt bør baseres på evidens i form af forskningsresultater. I sin mere folkelige form kan dette krav medføre, at dristige og kreative ideer kvæles, såfremt de ikke må afprøves inden der foreligger et systematisk review om hidtidige erfaringer. Professor Hanne Nørreklit fra Handelshøjskolen i Århus taler her om, at vi lever i en performancekultur, hvor præstationer i stigende grad bliver målt og vejet, hvilket hun mener skader både kreativiteten og problemløsningen (Meier Carlsen, 2009). Her ses tilsyneladende bort fra, at man ikke så sjældent ser, at ideer og koncepter, som man fx i andre lande har haft dårlige erfaringer alligevel anvendes igen og igen uden, at man gør sig den ulejlighed at søge litteratur om emnet.

Det er imidlertid en udbredt misforståelse, at EBP betyder, at principperne skal anvendes i enhver situation og kontekst. Mandagmorgen (2004) understreger fx - som allerede nævnt - at evidens netop ikke er 
velegnet til at behandle det, der foregår i det personlige møde mellem bruger og offentligt ansat. Også på det principielle plan erkender tilhængere af EBP, at evidens har svagheder og risici og derfor ikke passer til alle situationer. Specielt i situationer, hvor helt nye ideer opstår, kan det være svært at drage vidtgående konklusioner på områder, hvor der endnu ikke findes stabile og velkendte metoder (Mandagmorgen, 2004, s. 36 og 41). I situationer, hvor engagerede fagfolk afprøver deres bedste ideer i praksis, og hvor hverken indsatsen eller vurderingskriterierne er beskrevet og fastlagt på forhånd, men opstår hen ad vejen, kan enkeltstående projekter med tilhørende evaluering være en mere hensigtsmæssig metode end et systematisk review. En kritiker af evidens har formuleret denne sammenhæng meget præcist: "Evidensbølgen vidner om, at man ikke kræver ny viden, man kræver sikkerhed" (Hyldgaard, 2010). Min pointe er her, at evidensbevægelsen ikke anbefaler EBP som et universelt virkemiddel til alle situationer og kontekster, men som et sæt principper der kræver, at en række specificerede forudsætninger er opfyldt (i øvrigt henvises her til Christine Nordentofts artikel i dette temanummer om hendes undersøgelser af danske bibliotekslederes holdninger til innovation og kreativitet).

\section{Evidens i samfundsvidenskabelige retninger}

Bibliotekerne er ligesom andre offentlige institutioner påvirket af herskende retninger, paradigmer og modestrømninger inden for især samfundsvidenskab og humaniora. Tendentielt er påvirkningen antagelige stærkere i dag end for 10 år siden, idet mange biblioteksledere i forbindelse med forskellige efteruddannelsesaktiviteter og masteruddannelser har stiftet bekendtskab med organisationsteoretiske og samfundsvidenskabelige kernebegreber såsom virksomhedskultur, social kapital, performancemåling, osv.

Nu er det sjældent sådan, at de enkelte teorier og begrebsdannelser direkte opererer med en afgrænsning over for og en stillingtagen i forhold til evidensbasering i almindelighed og da slet ikke til EBP i særdeleshed.

Undersøgelsen vil derfor i højere grad tage sigte på at undersøge, hvorvidt der skulle være indbyrdes modstridende metodemæssige præferencer og videnskabsteoretiske orienteringer mellem evidensbevægelsen og de pågældende retninger, idet man kan forestille sig, at sådanne modsætninger eller overensstemmelser kunne have en vis indflydelse på, hvordan EBP bliver modtaget i BDI-sektoren. Hvis fx evidens bliver opfattet bredt som et forældet og bureaukratisk koncept af bibliotekarer og biblioteksledere, vil det i sig selv kunne få indflydelse på evidensprincippernes udbredelse.

Jeg vil i det følgende gennemgå følgende fem overvejende samfundsvidenskabelige retningers respektive overens- og uoverensstemmelser med EBP: 1) effektmåling; 2) evalueringer som ritual; 3) institutionel teori; 4) organisationskultur; og 5) social kapital.

\section{Effektmåling}

Effektmåling - på engelsk: performance measurement - har i den senere tid haft en betydelig indflydelse i danske folkebiblioteker. Det skyldes dels ydre krav om dokumentation af effektivitet og produktivitet og dels et ønske om at finde alternativer til udlånstallet, der tidligere næsten var enerådende som indikator for bibliotekernes virksomhed. Ønsket om alternativer og et supplement til udlånstal er begrundet i den stigende efterspørgsel efter nye medier som CD, DVD og downsloads og den tilsvarende stagnerende interesse for de trykte bøger. Bag interessen for nye indikatorer ligger også et ønske om at dokumentere andre aspekter og sider af bibliotekernes virksomhed end udlån fx besøgstal generelt og mere specifikt antallet af deltagere i bibliotekernes arrangementsvirksomhed.

Effektmåling har da også nydt stor bevågenhed fra centrale bibliotekspolitiske aktører som Danmarks Biblioteksforening, der siden 1998 har bidraget med flere bøger om emnet (Pors, 1998; Pors, 2007). Formålet med 2007 publikation var at bidrage til en kvalificering af de politiske beslutningsprocesser omkring bibliotekernes opgaver og placering i de nye storkommuner efter kommunalreformen i 2007. Indikatorerne skulle her sikre "klarhed, kvalitet, innovation og sammenhæng i biblioteksbetjeningen" og "effektivitet og bedre ressourceudnyttelse" i opgaveløsningen i den enkelte kommune. Af andre formål nævnes ønsket om en metode, der i alle landets kommuner på en ensartet måde kan tydeliggøre den værdi kommunerne og samfundet får ud af at investere i folkebiblioteker og skabe større "gennemsigtighed" i forhold til borgerne (Pors, 2007a, s. 3). 
Bhatti, Foss Hansen og Rieper (2006, s. 9-10) ser i deres kortlægningsrapport om evidensbevægelsens udvikling, organisering og arbejdsform en tydelig sammenhæng mellem EBP og tre megatrends (hvoraf effektmålinger er den ene). De to andre er evalueringsbølgen og kvalitetssikring og -udvikling. Samtidig peger de på, at bevægelsens evidensproducerende organisationer repræsenterer noget helt nyt ved at gøre professionel praksis og politik mere videnbaseret.

EBP adskiller sig fra traditionelle effektmålinger ved tre ting: 1) Snævert fokus på effekter - om indsatser og interventioner virker eller ikke virker; 2) systematisk og obligatorisk inddragelse af forskningsresultater og 3) sofistikerede metoder til sammenfatning og syntetisering af viden. Sat lidt på spidsen kan man sige, at evidenstilgangen er mere analytisk end performancemålinger, idet førstnævnte altid vil have en klar men også snæver problemstilling - virker indsats $\mathrm{X}$ eller virker den ikke - som udgangspunkt, mens sidstnævnte ofte kan have et bredere, mere beskrivende sigte. Så i den forstand kan man sige, at det har skabt et behov for en forskningsbaseret sammenfatning af informationer om opnåede virkninger. Fælles for performance måling og evidensbasering er en enighed om betydningen af at stille kvalificeret viden til rådighed for beslutningstagere i politik og praksis. Begge retninger har også en forståelse af sig selv som værktøjer i en politisk og faglig prioriteringskontekst og grundlæggende er erkendelsesinteressen for evidens og performancemålinger den samme: hvad kan bibliotekerne gøre for at opnå bestemte ønskede virkninger? Og hvilke indsatser og interventioner virker i forhold til deres formål?

\section{Evalueringsteori}

Evalueringsbølgen er en anden af de megatrends, som antages at have både influeret på og skabt behov for evidensbevægelsen, idet det store antal evalueringer på specifikke områder skaber behov for sammenfatninger og oversigter over resultater. Evalueringer kan i bund og grund forstås som en videnindsamling, der foretages med henblik på at styre og/eller forbedre en indsats. Forskning viser dog her, at anvendelsen enten ikke sker eller bliver anderledes end tilsigtet. På den baggrund er det blevet påpeget, at evalueringer ofte har en rituel og symbolsk karakter uden nævneværdig indflydelse på praksis (Dahler-Larsen 1998). Ikke desto mindre må evalueringsbegrebet siges at have haft afgørende indflydelse på evidensbevægelsen i den forstand, at evalueringsdiskussion har været med til at sætte evidens på dagsordenen inden for uddannelsessektoren. Dahler-Larsen (2006, s. 17-20) skriver nemlig, at offentliggørelsen af OECDs undersøgelse af den danske folkeskoles stærke og svage sider i 2004 var med til at sætte begrebet "evalueringskultur" øverst på den politiske dagsorden, samtidig med, at et forskerteam fra Danmarks Pædagogiske Universitetsskole tillægger OECD en tilsvarende afgørende betydning for lanceringen af evidens som et nøglebegreb i moderniseringsdiskursen (Moos et al. 2008, s. 14). Selvom begreberne evidens og evaluering tydeligvis er beslægtede, gør væsentlige forskelle sig gældende. Klassisk evidenstænkning med dens klare fokus på effektivitet har således et snævrere sigte end evalueringstilgangen, der opererer med mindst seks meget forskellige teoretiske perspektiver: målopfyldelse er her det perspektiv, der er mest beslægtet med evidens, hvorimod de øvrige (intern-proces-, system-, interessent-, symbolik- og paradoksperspektivet) i varierende omfang adskiller sig fra evidensprincipperne. Især de to sidstnævnte, symbolik- og paradoksperspektivet, hvor førstnævnte vurderer en organisation som effektiv, hvis den "evner at fremstille sig som effektiv i forhold til interne og eksterne interessenter", hvorved kriteriet for effektivitet skifter karakter fra at være et substanskriterium til et symbolkriterium, mens paradoksperspektivet ser modsætningsfyldte karakteristika og interne inkonsistenser som $\mathrm{fx}$ centralisering og decentralisering på samme tid som konstruktive, energiudløsende spændinger (Christiansen og Foss Hansen,1993, s. 200-213).

En anden iøjnefaldende forskel mellem evaluering og evidens er, at evalueringer ofte i praksis accepterer væsentlig blødere krav til undersøgelsesdesign end foreskrevet af evidenshierarkiet og evidenstypologien. Det betyder, at mange evalueringer $\mathrm{fx}$ fra BDI-sektoren hverken lever op evidenshierarkiets strenge krav til inklusion, der typisk er lodtrækningsforsøg/ RCT, der er den "gyldne standard" for forskningsdesign, eller tilfredsstiller evidenstypologiens mere problemstillingsafhængige krav til udsagnskraft (Rieper og Foss Hansen. 2007, s. 78-88). Fx er det sjældent forekommende i evalueringer af biblioteksforsøg, at der optræder en kontrolgruppe - i mange tilfælde fordi det ikke er praktisk muligt - ligesom randomisering (stikprøveudvælgelse) fx til interviews er sjældne. Det kan imidlertid også diskuteres, 
hvorvidt evidensprincipper er hensigtsmæssige som norm i alle evalueringskontekster.

Mandagmorgen (2004, s. 27-28) anbefaler her, at kravene til systematisk evidensbasering gøres gældende, når det offentlige efterspørger evalueringer og udredninger. Det kunne fx være et krav om at vælge metoder med høj evidens eller i hvert fald argumentere og forklare, hvis man alligevel har valgt metoder med lav evidensstyrke, eller at man per automatik skulle argumentere for, hvorfor man har valgt at gennemføre en evaluering uden en kontrolgruppe til sammenligning. Det understreges, at sådanne forklaringer kan vise sig at være fuldstændig legitime fx ved et eksplorativt projekt, eller hvor kontrolgrupper enten ikke er praktisk mulige eller etisk forsvarlige. Der argumenteres ydermere for, at mere formelle kvalitetskrav til metode kan bidrage til at øge den reelle uafhængighed, idet stærkt politisk farvede evalueringer udarbejdet for at forsvare allerede fastlagte politikker ville blive nemmere at gennemskue.

Pointen med, at evidensbasering er mindre velegnet ved nye indsatser - fx eksplorative projekter - er bredt anerkendte inden for evidensbevægelsen selv (Mandagmorgen,2004, s. 17; Rieper og Foss Hansen, 2007, s. 82-83). I evalueringsteori er det nemlig almindeligt anerkendt, at interventionens grad af udvikling er afgørende for valg af evalueringsdesign. Inden for lægemiddelafprøvning, hvor RCT er anvendt, hører designet til i en bestemt fase i afprøvningsprocessens fire faser. RCT anbefales her først anvendt i den tredje fase. De to forudgående faser er: 1) små eksplorative studier af få cases og 2) statistiske studier baseret på korrelationsanalyser. Ræsonnementet kan uden besvær overføres til BDIsektoren, hvilket betyder, at forløbsundersøgelser og case-studier fint kan være mere hensigtsmæssige designs end RCT ved eksplorative studier af nye services, hvor formålet ikke er at kvalificere en stop/go beslutning, men mere handler om tilpasning eller forståelse af indsatsen. På den baggrund vil det kræve en dybere analyse af evalueringernes formål, inden man kan sige, i hvilken udstrækning anvendelse af andre designs til evaluering i BDI-sektoren er metodisk set problematiske eller ej.

\section{Institutionel teori}

Hvad angår den tredje samfundsvidenskabelige retning, institutionel teori, har jeg valgt at tage mit af- sæt i nordmanden, Kjell Arne Røviks (1998; 2007) forskning. Inden for institutionel teori placerer Røvik (2007) sig mellem en modernistisk og socialkonstruktivistisk tilgang i en mellemposition, som han selv betegner som "pragmatisk institutionalisme". Røvik (1998) er særlig kendt for sit begreb om de populære organisationsopskrifter som både rejser hurtigt og langt. Det er nærliggende her at betragte EBP som en sådan opskrift.

Han har yderligere beskæftiget sig med, hvordan bestemte opskrifter har sat dagsordenen i forskellige årtier. 1960erne var således rationaliseringens årti, i 1970erne fulgte de "politiserte oppskrifters tiår", 1980erne var tiåret for de store ledelsessatsninger og endelig bød 90erne på "slankeoppskrifter" (Røvik, 1998, s. 171-278). Nu synes evidensprincipperne ikke at være inddraget i Røviks analyser af spredningen af populære organisationsideer fra 1960erne og fremad til det tidlige 2000-tal (Røvik, 2007), hvilket utvivlsomt hænger sammen med, at evidens ikke opfattes som en organisationside til trods for, at viden og læring spiller en fremtrædende rolle i retninger som den lærende organisation og vidensorganisationer.

Ligheden med EBP synes derfor overfladiske. Ikke desto mindre synes Røviks teori om spredning af organisationsopskrifter fint at kunne anvendes på andet end management- og ledelsesprincipper. Teorien beskæftiger sig både med hvilke forhold, der påvirker en opskrifts spredbarhed eller udbredelsesevne, og hvad der sker, når en institutionaliseret organisationsopskrift rejser ind i organisationen. Sidstnævnte problemstilling handler om, hvorfor og hvornår organisationer motiveres til at adoptere en opskrift på rejse, hvad der sker med den populære opskrift, når den indføres i organisation og endelig, hvad optagelsen betyder for organisationen (Røvik, 1998, s. 108-114).

Syv elementer synes at påvirke en opskrifts udbredelsesevne. Et er "social autorisering", som handler om, at en opskrift helst skal formidles af instanser, der opfattes som autoritative af store grupper organisationer. Overført til evidens kan det således betragtes som socialt autoritetsskabende, at instanser som Rigshospitalet, Socialforskningsinstituttet og Danmarks Pædagogiske Universitetsskole står bag, huser eller på anden måde støtter evidensproducerende organisationer. I bibliotekssektoren vil helhjertet opbakning fra fx Styrelsen for Bibliotek og Medier, 
Danmarks Biblioteksforening og Det Informationsvidenskabelige Akademi tilsvarende kunne styrke evidensprincippernes udbredelse i danske folkebiblioteker. En variant af denne argumentation (Booth og Brice, 2004a, s. 3) handler om, at import af nøglebegreber fra en prestigepræget branche, medicin, der sædvanligvis tillægges stor autoritet kan have spillet og fortsat spiller en rolle. Omvendt er der også en risiko for, at oversættelser fra meget naturvidenskabeligt orienterede kontekster som medicin til mere humanistiske bibliotekssammenhænge kan besværliggøre den sociale autorisering. Mere problematiske er derimod forestillingerne om opskriftens "teorisering", der henviser til ,at dens succes handler om at fremstille den som et universalmiddel, der virker i henhold til universelt gyldige kausalsammenhænge. Tværtimod synes det hidtil at være en svaghed, at EBP - ganske vist noget uberettiget - af kritikere bl.a. fra Danmarks Pædagogiske Universitetsskole (Moos et al, 2008) anklages for at være udråbt til et kontekst- og situationsuafhængigt universalmiddel. Andre faktorer såsom produktivering, harmonisering, dramatisering og individualisering antages at kunne influere positivt på opskrifters spredningsevne. Jeg vil her indskrænke mig til at nævne tidsmarkering, der pointerer vigtigheden af at tidsmarkere rigtigt typisk ved at definere opskriften som et moderne og tidssvarende svar på omgivelsesdrevne ændringsprocesser og som en ny, fremtidsorienteret og bedre opskrift.

Der er tre forskellige teoretiske forklaringer på, hvorfor organisationer motiveres til at indoptage eller adoptere en opskrift (Røvik,1998, s. 118-144). Den ene repræsenterer en traditionel rationalistisk forståelse, hvor adoptering ses som en reaktion på objektive organisationsinterne problemer eller sygdomme. Oversat til bibliotekssektorens kontekst kan man her sige, at EBP er et svar på stigende kompleksitet - teknologisk og hvad angår efterspørgsel - i bibliotekernes serviceleverancer. Man ønsker evidens, fordi det ikke er umiddelbart gennemskueligt om bestemte indsatser virker efter hensigten. I forbindelse med Styrelsen for Bibliotek og Mediers rapport "Folkebibliotekerne i vidensamfundet" (2010, side 12) finder vi en argumentation beslægtet hermed:

"For at sikre at biblioteksbetjeningen i større omfang baseres på evidensbaseret viden, iværksættes en proces, der skal udbygge den evidensbaserede viden om bibliotekernes effekt og om ønsker og behov hos bibliotekernes brugere og ikke-brugere."

En alternativ forklaring - inspireret af nyinstitutionel teori - udfordrer forestillingen om, at det er interne, objektive problemer, som driver en institution til at adoptere populære opskrifter. Den nyinstitutionelle teori derimod lægger vægt på, at omgivelserne leverer ikke blot opskrifterne men også problembeskrivelserne til institutionerne. Problemdefinitionerne er således også tidstypiske og eksternt skabte. Problemerne beskrives i denne sammenhæng som tilnærmet universelle som noget alle organisationer enten allerede er ramt af eller vil blive ramt af i nærmeste fremtid. Ikke blot løsningerne men problemerne bliver hermed mere eller mindre standardiserede. Dette skaber en situation, hvor det ofte er svært at skelne mellem, hvad der kommer først: problemet eller løsningen.

Man kan her argumentere for, at fx generelle ledelseskurser, specielt hvor forskellige grene af den offentlige sektor er repræsenterede, tendentielt gøres ens, og der udvikler sig forestillinger om organisatoriske "børnesygdomme" fælles for biblioteker, offentlige forvaltninger, skoler, m.fl. Ligesom lægen og sygeplejersken har et stigende behov for evidens i deres arbejde, har bibliotekaren, læreren og sagsbehandleren det samme, fordi vi alle sammen er underlagt de samme samfundskræfter og mekanismer.

En tredje, mulig forklaring på, hvorfor organisationer ofte motiveres til at adoptere populære koncepter kan - efter Røvik - benævnes pragmatisk institutionalisme. Ræsonnementet går ud på, at man er specielt motiveret til at adoptere, når ens identitet udfordres og opleves som problematisk. På den baggrund han indoptagelse af opskrifter forstås som en form for "organisationsmæssig identitetsforvaltning". På baggrund af de senere års intense debat om identitetsspørgsmål i forhold til folkebibliotekerne er det nærliggende at hæfte sig især ved sidstnævnte forklaring. Ikke blot som en nøgle til at forstå, hvorfor evidensspørgsmålet er kommet på bibliotekernes dagsorden men måske endnu vigtigere for at forklare noget af den modstand, der er mod EBP i bibliotekssektoren. To centrale identitetsudviklende processer gør sig gældende: sammenligning og kontrastering, hvor divergenser med hensyn til hvem man gerne vil ligne, og hvem man ønsker at lægge afstand til kan være afgørende for, hvordan man stiller sig til EBP. 
Sammenfattende kan man ikke sige, at de forskellige ovenfor præsenterede tilgange, der alle er inspireret af institutionel teori, forholder sig grundlæggende kritisk endsige afvisende i forhold til EBP. Dog er de heller ikke ukritiske for så vidt, som de åbner op for, at moderetninger og identitetsspørgsmål også kan spille en rolle for et koncepts popularitet eller mangel på samme ved siden af funktionelle betragtninger. En anden vigtig pointe, som kan udledes af den institutionelle teori, lægger op til temaet for ovenstående afsnit, der handler om kritikker, der ser EBP som et udtryk for en tænkning baseret på management og New Public Management, NPM. .

\section{Organisationskultur}

Organisationskultur er en retning som har haft stor gennemslagskraft inden for BDI-sektoren i de senere år. Det skyldes bl.a. tilgangens oplagte relevans i forhold til de utallige og omfattende biblioteksfusioner i kølvandet på Kommunalreformen 2007 og vel også en voksende erkendelse af, at kendskab til kulturen som oftest er en forudsætning for vellykket innovation og forandringsprojekter.

I sin klassiske udformning (Schein,1994) refererer kultur til de elementer i en gruppe eller organisationer, der er mest stabile og mindst påvirkelige. Ofte er kulturens dybeste lag, de såkaldte "grundlæggende antagelser", der består af "tages-for-givet" anskuelser tilmed ubevidste. Ifølge Schein er kulturen resultatet af en indviklet gruppelæreproces, som kun delvist er påvirket af lederadfærd. I situationer hvor gruppens fx bibliotekets overlevelse er truet, fordi dele af dens kultur passer dårligt til omgivelsernes krav, er det dog til syvende og sidst ledelsesfunktionens opgave at erkende det og gøre noget ved situationen (Schein, 1994, s. 12-14). I forhold til EBP i biblioteker rejser organisationskulturtilgangen to spørgsmål: 1) I hvilken udstrækning er der i danske folkebibliotekers kulturs dybeste lag, værdier og antagelser, der kan påvirke indstillingen til EBP? Og i hvilken udstrækning befinder folkebibliotekerne sig i en situation, der nødvendiggør en kulturændring i forhold til synet på EBP? Ikke kun kulturens grundlæggende antagelser er i spil her; også på artefaktniveauet, som rummer alle de fænomener som man ser, hører og føler, når man besøger en organisation og altså også den måde man i biblioteket træffer beslutninger om nye eller ændrede services vil kunne blive påvirket af evidenstænkningen.
Ligesom med institutionel teori er det oplagt, at også kulturbetragtningen er relevant og frugtbar, ligesom problemstillingen involverer dybereliggende spørgsmål om identitet, mening og autencitet. Er EBP med vægt på forestillingen om sikker viden, nøje fastlagte procedurer og strenge dokumentationskrav foreneligt med en identitet som rummelig og innovativ kulturinstitution? Og omvendt: vil en mere systematisk tilgang til effektivitets- og hvad-virker-spørgsmål ikke i virkeligheden styrke bibliotekets troværdighed og sikre, at det håndterer sine kerneopgaver på en effektiv og hensigtsmæssig måde? Det er her principperne om EBP går ned og udfordrer veletablerede forestillinger på en frugtbar måde, idet organisationskulturteorien i Scheins klassiske udformning ikke ser kulturen som et uforanderligt endsige urørligt område.

Sammenfattende kan man argumentere for, at den af Schein inspirerede organisationskulturteori både kan levere skyts til modstand og forsvar mod EBP i BDI-sektoren. En modstand kan begrundes i, at evidensprincipperne er i modstrid med grundlæggende værdisæt i bibliotekerne: et forsvar kan bygge på, at en eksisterende evidensfjendtlig kultur er en hindring for bibliotekernes fortsatte vækst og - i værste fald - overlevelse i det moderne samfund. Som allerede nævnt synes modtagelsen af EBP i bibliotekskredse i Norge og Sverige (se Haglund i dette temanummer; Ôgland, 2010) i høj grad at indeholde stærke organisationskulturelle elementer og præferencer. Den sidste i rækken af samfundsvidenskabelige tilgange er social kapital.

\section{Social kapital}

Begrebet social kapital har i de senere år været genstand for stor og voksende interesse i specielt folkebibliotekerne. En medvirkende årsag hertil er sandsynligvis, at forskere uden for bibliotekssektoren har lagt mærke til, at biblioteker kan have en positiv rolle i forhold til et samfunds muligheder for at udvikle og styrke dets sociale kapital.

Der findes mange definitioner af social kapital. Putnams definition af social kapital som "netværk, normer og tillid, som letter koordinering og samarbejde til fælles gavn" (citeret efter Tinggaard Svendsen, 2006, s. 36-39) vil jeg her fremhæve fordi den 1) inviterer til undersøgelser af social kapital på et kvantitativt og statistisk orienteret grundlag og 2) fordi især tillid spiller en central rolle. Vi står her overfor en 
begrebsdannelse, der kombinerer økonomiske målbare størrelser med positive menneskelige værdier via begreber som økonomiske transaktionsomkostninger, politologiske institutioner og sociologiske normer (Tinggaard Svendsen, 2006). Graden af tillid er i store spørgeskemaundersøgelser som World Values Survey målt, som de der svarer bekræftende, når de bliver spurgt, om de mener, at man kan stole på de fleste andre mennesker (Tinggaard Svendsen,2006, side 86). Det overordnede spørgsmål er her, om EBP kan siges at påvirke den generelle tillid i negativ retning, eller om referencer til evidens omvendt øger den generelle tillid. Jeg finder lidt problematikken afspejlet i debatten om folkeskolelærernes position, hvor tilhængere af evidens betoner, at referencer til forskning kan styrke lærerens position i forhold til forældrene og dermed - måske - styrke den generelle tillid til professionen.

\section{Evidenskritikkens effekter}

I dette afsnit vil jeg se nærmere på, hvilke effekter kritikken mod evidens har haft på evidensbevægelsens udvikling i Danmark. Umiddelbart kan man konstatere, at den voldsomme kritik, der har kendetegnet reaktionerne i uddannelsessektoren tilsyneladende ikke har kunnet forhindre etablering af en livskraftig evidensproducerende organisation, Dansk Clearinghouse for Uddannelsesforskning i 2006. Tværtimod synes det som om, at kritikken er forstummet i takt med, at centret har påbegyndt sin virksomhed. Ser vi på sundheds- og den sociale sektor synes den mere begrænsede kritik inden for disse områder heller ikke i nævneværdigt omfang at have forhindret princippernes adoption og spredning $\mathrm{i}$ Danmark fra hhv. 1993, hvor Nordic Cochrane Center oprettes og 2002, hvor institutionaliseringen af reviewarbejdet på socialområdet institutionaliseredes med etableringen af Nordic Campbell Center i 2002 (Bhatti, Foss Hansen og Rieper, 2006).

Vender vi os mod BDI-sektoren, hvor der stort set ikke har været rejst nogen nævneværdig substantiel kritik mod evidensbevægelsen, synes princippernes gennemslagskraft temmelig begrænsede især, hvis vi vælger at fokusere specifikt på folkebibliotekerne. Her er der ikke blevet oprettet evidensproducerende instanser eller clearinghouses, ligesom interessen for at lære evidensprincipperne nærmere at kende har været såre begrænset fx målt i forhold til tilmeldinger til temadage om emnet og artikler om debat om emnet i fagtidsskrifter o.l. Der er enkelte ildsjæle, der har skrevet om emnet og markeret interesse ved deltagelse i de årlige internationale Evidence Based Library and Information Practice (EBLIP) konferencers afholdt siden 2004, men alt i alt har danske folkebiblioteker ikke grebet fat i evidensprincipperne endnu. Både i Sverige og Norge synes interessen specielt i forskningsbibliotekskredse noget større. Kan forklaringen være den, at kritikken har overbevist bibliotekarerne om princippernes mangel på holdbarhed eller har den manglende gennemslagskraft sin rod i andre faktorer. Spørgsmålet er blevet behandlet i artiklen "Why don't librarians use research?" (Genoni, Haddow og Ritchie, 2004). Artiklen peger på, at bibliotekarprofessionen ikke er den eneste, hvor praktikere forsømmer at udnytte forskning. Det samme skulle også gælde for psykologer og sygeplejersker.

For det andet synes vor viden om bibliotekarers læsevaner og brug af forskning at være fragmentarisk. Ikke desto mindre synes hovedtendensen at være, at der i BDI-sektoren eksisterer en kløft mellem praktikere og forskere med en megen sparsom gensidig ideudveksling. Baggrunden for denne kløft angives primært som begrundet i mangel på tid ("time constraints") (Turner, 2002). Dette er bemærkelsesværdigt eftersom netop bibliotekarprofessionen ellers skulle være i besiddelse af medfødte fordele såsom fortrolighed med informations- og litteratursøgning og træning i kvalitetsbedømmelse af litteratur. På den anden side tyder den internationale biblioteksforskning på, at faktorer som kommunikationskløfter mellem forskning og praksis mere end fx modvilje mod evidensbevægelsens videnskabsteoretiske fundament rummer forklaringen på biblioteksprofessionens manglende anvendelse af forskning. Genoni, Haddow og Richi (2004) peger på samarbejdsmodeller mellem praktikere og forskere og prioritering af forskningsmetode i bibliotekaruddannelsen som mulige midler til at udjævne kommunikationskløften mellem praktikere og forskere.

\section{Konklusion}

Det første af de seks forskningsspørgsmål drejer sig om de anledninger og kontekster, hvor kritikken af evidensprincipperne er blevet fremsat i Danmark. Her har mine undersøgelser afdækket et karakteristisk mønster for uddannelsessektoren, hvor kritikken så at sige kommer forud for det fænomen, som den retter sig imod. Det skal forstås på den måde, at 
der i forbindelse med italesættelsen af planerne om at etablere en evidensproducerende organisation i 2004 artikuleres en omfattende kritisk virksomhed, der senere hen dæmpes betydeligt i takt med, at Dansk Clearingcenter for Uddannelsesforskning etableres i 2006 og starter sin virksomhed og senere også i takt med, at DPU's ledelse fra 2008 eksplicit bakker op omkring evidensprincipperne. Dette hændelsesforløb indicerer, at den oprindelige kritik har indeholdt misforståelser omkring evidens, som der med centrets virksomhed er blevet rettet op på. Hvad angår sundheds- og socialsektoren synes der derimod ikke at have været iøjnefaldende sammenhænge mellem kritikken og evidensproduktionens institutionalisering.

Hvad angår forskningsspørgsmål nummer to: Hvem og hvilke aktører står bag kritikken, og hvilke interesser har gjort sig gældende synes mønstret herhjemme - igen med afsæt i uddannelsessektoren at være, at kritikken har haft sit institutionelle udspring i pædagogiske forskerkredse omkring DPU, hvor dels forskerinterne kriterier af videnskabsteoretisk art og professionsorienterede argumenter med afsæt i et ønske om at fastholde en professionelt råderum har været bragt i spil. Senere hen har også lærerprofessionens praktikere taget del i debatten - for det meste med kritiske udmeldinger.

Ser vi på den tredje problemstilling, der omhandler kritikkens nærmere karakter, viser gennemgang, at såvel videnskabsteoretiske forbehold, trusler mod professionelles råderum og skøn og formodede trusler mod kreativitet og innovation har været fremme. Derimod har modvilje mod New Public Management kun spillet en minimal rolle.

I henhold til undersøgelsen af relationerne mellem evidens og udvalgte samfundsvidenskabelige positioner resulterede drøftelsen i flere pointer. For det første syntes evidensprincipperne at indeholde distinkte elementer - trods lighedspunkter - i forhold til klassisk effektmåling og evalueringsvirksomhed. De distinkte træk udgøres af elementer som kritisk og systematisk brug af forskning og rigoristiske og stringente udvælgelses- og vurderingsprincipper. Omkring institutionel teori og specielt den Røvikske tilgang til konceptmigration er det karakteristisk, at evidens ikke opleves som et erhvervslivsorienteret managementkoncept. En tredje pointe med særlig relation til feltet organisationskultur er, at det er vanskeligt at udlede entydige anbefalinger eller misrekommanderinger ud fra organisationskulturbetragtninger. Selvom evidensprincipperne skulle vise sig at være i regulær modstrid med grundlæggende antagelser i et bibliotek, kan der nemlig godt alligevel være basis for en ændring af kulturen, hvis den udgør en barriere for fremtidig fornyelse og videreudvikling.

Det næstsidste forskningsspørgsmål omhandlende evidenskritikkens holdbarhed, vil jeg her henholde mig til en enkelt gennemgående iagttagelse, nemlig, at kritikken i mange tilfælde har været diffus og upræcis, og blandet overordnede betragtninger omkring forskellige erkendelsesinteressers og forskningsspørgsmål berettigelse med mere konkrete overvejelser over forskellige undersøgelsesdesigns relative udsagnskraft. Det er fx ikke specielt legitimt endsige frugtbar at kritisere RCT og lodtrækningsforsøg for ikke at tilgodese brede, emancipatoriske erkendelsesinteresser. Til gengæld kan hverken hermeneutiske og fænomenologiske designs konkurrere med RCT, når det gælder udsagnskraft i forhold til effektstudier.

I henhold til den sjette problemstilling om, hvilken effekt kritikken har haft vil jeg fremhæve to sektorer: undervisning og biblioteker. I forhold til førstnævnte har den nok så hårde kritik på den ene side ikke formået at forhindre evidensbevægelsen $\mathrm{i}$ at opnå et stærkt institutionelt fodfæste i det pædagogiske forskningsmiljø på DPU. På den anden side har kritikken uden tvivl stimuleret Dansk Clearingcenter for Uddannelsesforskning i retning af præcision og kant i forhold til kontroversielle videnskabsteoretiske positioner. Omkring BDI-sektoren, hvor der ikke har været nogen nævneværdig kritik af evidens, men hvor der på den anden side heller ikke er foregået indsatser af mere varig betydning, er spørgsmålet om effekt mere komplekst. Det er her overvejende sandsynligt, at den svage adoption af evidensprincipperne af praktikere ikke hænger sammen med en kritisk grundholdning af videnskabsteoretisk eller professionsorienteret art, men i højere grad hænger sammen med pragmatiske faktorer såsom tidsmangel og præferencestrukturer. 


\section{Referencer}

Audunson, R (2009). Fra synsing til kunnskapsbasert praksis. Bok og Bibliotek, nr. 2, 12-13.

Bhatti, Y, Foss Hansen, H \& Rieper, O (2006). Evidensbevagelsens udvikling, organisering og arbejdsform - en kortloegningsrapport. København: AKF Forlaget.

Booth, A (2002). Librarian Heal Thyself: evidence based librarianship, useful, practicable, desirable? Proceedings of the 8th International Congress on Medical Librarianship held between July 2 and 5, 2000, London, UK. www.icml.org/tuesday/themes/ booth.htm (lokaliseret 23.2.2011)

Booth, A \& Brice, A (eds.) (2004). Evidence-based practice for information professionals - a handbook. London: Facet Publishing.

Booth, A \& Brice, A (2004a). Why evidence-based information practice? I: A. Booth, \& A. Brice (Eds.), Evidence-based practice for information professionals - a handbook (s. 1-12). London: Facet Publishing.

Booth, A \& Brice, A (2004b). Six domains of evidence-based information practice. I: A. Booth \& A. Brice (Eds.), Evidence-based practice for information professionals - a handbook (s. 144-147). London: Facet Publishing.

Brophy, P (2009). Narrative-based Practice. Farnham: Ashgate.

Bruun, J J, Hanak, ML \& Koefoed, B G (Red.) (2004). Viden og evidens i forebyggelsen. København: Sundhedsstyrelsen.

Christiansen, JK. \& Foss Hansen, H (1993). Forskningsevaluering i teori og praksis. Frederiksberg: Samfundslitteratur.

Crumley, E \& Koufogiannakis, D (2002). Developing Evidence-Based Librarianship: practical steps for implementation. Health Information and Libraries Journal, 19(4), 61-70.
Dahler-Larsen, P (1998). Den Rituelle Refleksion - Om evaluering $i$ organisationer. Odense: Odense Universitetsforlag.

Dahler-Larsen, P (2006). Evalueringskultur - et begreb bliver til. Odense: Syddansk Universitetsforlag.

Ebsen, F (2005). Betal tilbage! Social Kritik, nr. 102, 10-30.

Ekeland, T-J (2005). Kvalitetssikring eller instrumentalistisk fejlgreb. Social Kritik, nr. 102, 34-47.

Eldredge, JD(2004). How good is the evidence base? I: A. Booth \& A. Brice (Eds.). Evidence-based practice for information professionals - a handbook (s. 36-48). London: Facet Publishing.

Eldredge , JD (2002). Evidence-based Librarianship: What might we expect in the years ahead? Health Information and Libraries Journal, 19 (2), 71-77.

Fibæk Laursen, P (2006). Ja tak til evidens - rigtigt fortolket. Unge Padagoger, nr. 3, 3-13.

Genoni, P, Haddow, G \& Ritchie, A (2004). Why don't librarians use research? I: A. Booth \& A. Brice (Eds.). Evidence-based practice for information professionals - a handbook (s. 49-60). London: Facet Publishing.

Ghosh, F (2009). Tilbage til en menneskelig socialpolitik. Socialrådgiveren, den 22.1.2009, 22.

Gjersdal, A (2010). Kunnskapsbasert praksis i bibliotek.

www.norskbibliotekforening.no/article.php?id=2471 (besøgt 18.1.2011)

Grossman, J \& Leach, J (2008). The Rhetoric of Research Methodology. Social Epistemology, Vol. 22, no.4, October-December 2008, 325-331.

Gøtzsche, PC. et al. (2009). Videnskabelig uredelighed - ubegrundet anklage rejst af Lægemiddelindustriforeningen mod akademiske forskere havde karakter af chikane. Ugeskrift for Lager, 30.3.2009.

Hansen, EJ og Hjorth Andersen, B (2000). Et sociologisk varktøj - Introduktion til den kvantitative metode. København: Hans Reitzels Forlag. 244 sider. 
Hastrup, K (2004). Vidensbegreber og videnskaber: Nye veje til kundskab? I: JJ Bruun, ML Hanak \& BG Koefoed (Red.). Viden og evidens i forebyggelsen (s. 9-18). København: Sundhedsstyrelsen.

Hjort, K (2006). Evidens - hvorfor er det så indlysende? Dansk Pcedagogisk Tidsskrift, nr. 2, 54-63.

Hyldgaard, K (2010). Umuligheder: Imod sikker viden. Weekendavisen, 29.4.2010, 4.sektion, 12.

Johannsen, CG \& Pors, NO (2002). Udfordringer og forandringer. København: Danmarks Biblioteksforening.

Juul Jensen, U (2004). Evidens, viden og sundhedsfaglig praksis i filosofisk perspektiv - eller faren ved at være mere katolsk end paven. I: JJ Bruun, et al. (2004). Viden og evidens i forebyggelsen. København: Sundhedsstyrelsen. s. 19-29.

Lihme, B (2005). Social Kritik, nr. 102, 2-3.

Lihme, B (2005a). Kulturkamp. Social Kritik, nr. 102,52 .

Lihme, B (2005b). Når effektmålerne skyder ved siden af målet ... Social Kritik, nr. 102, 56-67.

Lihme, B (2005c). Når ledelse ikke længere er ledelse men styring. Social Kritik, nr. 102, 4-9.

Lihme, B (2006). Tro eller viden i narkobehandling - eller hvad med evidensbaseret tro? Social Kritik, nr. 104, 26-27.

Madsen, V (2008). Evidens kontra intuition. Folkeskolen, den 26.9.2008, 33.

Mandag Morgen (2004). Virker velforden - et debat oplaeg om evidens og velfcerd. Huset Mandag Morgen.

Meier Carlsen, J (2009). Mål mig her og mål mig der. Jyllands-Posten, den 15.2.2009, Erhvervsmaga$\sin , 2$.

Moos, L et al. (2008). Evidens i uddannelse? København: Danmarks Pædagogiske Universitetsforlag. (udkom første gang i 2005).
Moos, L et al. (2005). Evidens i uddannelse? Social Kritik, nr. 102, 53-57.

Nissen, P (2008). Virker det? : om evidens og effektmåling. Kognition \& pcedagogik, årg. 18, nr. 67, 36-43.

Nordenbo, SE (2010). Her er hvad vi ved om brugen af test. Politiken, den 22.februar.

Petticrew, M \& Roberts, H (2006). Systematic Reviews in the Social Sciences - A practical guide. Malden, MA: Blackwell Publishing.

Pors, NO (1998). Kvalitetsmålinger i folkebiblioteker. Ballerup: Danmarks Biblioteksforenings Forlag.

Pors, NO (2007). Strategi, vardi og kvalitet: Teorier og metoder 1. København: Danmarks Biblioteksforening.

Pors, NO (2007a). Strategi, vaerdi og kvalitet: Vaerktøjer og indikatorer 2. København: Danmarks Biblioteksforening.

Qvortrup, L (2008). Dannelse og evidens. Information, 9.5.2008, sektion 1, 17.

Qvortrup, L (2008a). Skoleelever skal under forskernes lup. Berlingske Tidende, 3.9.2008.

Qvortrup, L (2008b). Debat:Kommentar: Bevis: Hvornår er noget evident? Information, 30.4.2008, 1.sektion, 20-21.

Qvortrup, L (2008). Interview: Et gennembrud på vej i pædagogikforskningen. Information, 7.1.2008, 1.sekt.,12-13.

Rieper, O. \& Foss Hansen, H (2007). Metodedebatten om evidens. København: AKF Forlaget.

Rieper, O \& Foss Hansen, H (2006). Evidensbevægelsen: hvorfra, hvordan og med hvilke konsekvenser? Unge Pcedagoger, nr. 3, 27-34.

Røvik, K (1998). Moderne organisasjoner - Trender $i$ organisasjonstenkningen ved tusenårsskiftet. Bergen-Sandviken: Fakbokforlaget. 
Røvik, KA (2007). Trender og translasjoner - Ideer som former det 21. århundrets organisasjon. Oslo: Universitetsforlaget.

Salling Olesen, H (2006). Evidens, viden og profession. Social Kritik, nr. 104, 22-25.

Schein, EH (1994). Organisationskultur og ledelse. 2. udgave. København: Forlaget Valmuen.

Schmidt, E (2008). Qvortrups illusion om evidens. Information, 2.september 2008, 19.

Schmidt, B (2010). Hvad mistes ved evidensbasering? Sygeplejersken, den 20.5.2010,1. sektion, 38.

Schultz, M (1990). Kultur i organisationer - Funktion eller symbol. København: Handelshøjskolens Forlag.

Schultz Jørgensen, P (2010). Evidens - bevar det professionelle råderum. Politiken, den 14.6.2010, 8.
Sommerfeld, P (Ed.) (2005). Evidence-Based Social Work - Towards a new Professionalism? Bern: Peter Lang.

Styrelsen for Bibliotek og Medier (2010). Folkebibliotekerne i vidensamfundet - Rapport fra Udvalget om folkebibliotekerne $i$ vidensamfundet. København: Styrelsen for Bibliotek og Medier.

Søndergaard, J (2010). Vi famler i blinde i socialpolitikken. Politiken, den 27.5.2010.

Turner, K (2002). Do Information Professionals Use Research Published in LIS Journals? 68th IFLA Council and General Conference, August 18-24, 2002, www.ifla.org/IV/ifla68/papers/009-118e.pdf (besøgt 27.9.2010)

Vafai-Blom, S (2006). Evidens - hævet over enhver diskussion. Social Kritik, nr. 104, 20-21.

Ögland, Malin (2010). Interview den 8.december 2010 (upubliceret). 